\title{
The discipline that 'became': developments in music technology in British higher education between 2007 and 2018.
}

Russ Hepworth-Sawyer, York St John University, Nick Hughes, Robert Smyth Academy \& Research Student at Birmingham City University Dawid Ziemba, York St John University Carola Boehm, Staffordshire University

\begin{abstract}
In 2007 Carola Boehm published the introductory article within the first volume of the Journal of Music, Technology \& Education entitled 'The discipline that never was: current developments in music technology in higher education in Britain'. Boehm identified the higher education offerings in music technology at that time. In the ten or so years that have passed since those findings, we've witnessed both incredible growth in the HE sector and significant shift in the flavour of programmes on offer. This shift has been seen primarily in the growth of the creative practice-led title of 'music production', but not at the expense of traditional 'music technology'. Boehm's paper also explored the wider range of subject matters that could be considered within the then term 'music technology', whether by an ever-expanding technological backdrop, or through interdisciplinarity. In this paper, we report on the significant changes since then, with some analysis for the future whilst considering the current political challenges for British Higher Education.
\end{abstract}

\section{Introduction}

On 29th June 2017, York St John University hosted the first Music Production Education Conference (MPEC). Two of the authors Hepworth-Sawyer and Hughes outlined their current research project - titled Music Technology Education Provision \& Progression (MTEP) - focussing on the fluidity of music technology education in the UK. Principally MTEP is, and will be, gathering evidence around the matches and mismatches between each level and flavour of traditional music technology education and the progression routes covered by learners. In seeking clarity in the higher education area, it was clear Boehm's paper entitled 'The discipline that never was: current developments in music technology in higher education in Britain' was to be our starting point. In collaboration with Boehm, we now seek to provide an iterative 10 year update to the seminal paper from 2007.

\section{Boehm's Generations of the Music Technologist.}

In 2007's paper, Boehm explored the provision of higher education programmes in the field we knew then principally as Music Technology (Boehm, 2007). At that point in time, much of 
the term 'music technology' brought together under one umbrella concept a culmination of names contained and referred to in the field of audio, some new and some traditional.

Boehm traced the origins of the subject matter and suggested that considerable interdisciplinary areas converged to make up this new field - a 'discipline that never was'. Boehm noted that different types of universities hosted different types of course (Boehm, 2007).

Making sense of the field in 2007, Boehm self-deprecatingly offered an 'oversimplified' 'five generations of music technologists', which has today become highly cited and extremely relevant.

\begin{tabular}{|c|c|c|}
\hline Generation & Given Title & Description \\
\hline 1 & $\begin{array}{l}\text { Experimenters \& } \\
\text { Innovators }\end{array}$ & $\begin{array}{l}\text { 1950's \& 1960's. Boehm cites the likes of } \\
\text { 'Schaeffer, Stockhausen, Eimert, Cage, Moog, } \\
\text { Buchla, Mathews, Hiller'. Those who created the } \\
\text { technology or created the conditions for the 'music } \\
\text { technologist' to exist. }\end{array}$ \\
\hline 2 & 'Commercializers' & $\begin{array}{l}\text { 1970's \& 1980's. Academic embedding, as well as } \\
\text { exploitation of this new technology to the mass } \\
\text { market and to musicians as a whole community. } \\
\text { Boehm exemplifies the creation of MIDI in } 1983 \text { as } \\
\text { a key landmark for markets, and Kyma for DSP } \\
\text { creation. Boehm cited a number of key proponents } \\
\text { in this generation including 'Boulez, Risset, Vercoe, } \\
\text { Wishart, Puckett, Koening, Chowning \& Subotnik'. }\end{array}$ \\
\hline 3 & 'First Lecturers' & $\begin{array}{l}1990 \text { 's \& } 2000 \text { 's. Boehm cites the first lecturers in } \\
\text { 'music technology' en masse becoming the third } \\
\text { generation. This 'slowly' established the field as a } \\
\text { valid academic subject area. Technologically, } \\
\text { widespread introduction of digital audio equipment } \\
\text { (such as the ADAT) make the acquisition of studio } \\
\text { equipment more affordable. }\end{array}$ \\
\hline 4 & First Graduate Body & $\begin{array}{l}\text { Boehm cites the first generation of graduates from } \\
\text { those newly named courses. }\end{array}$ \\
\hline 5 & $\begin{array}{l}\text { First Post Graduate } \\
\text { Body }\end{array}$ & $\begin{array}{l}\text { Boehm cites the first post graduates and doctorates } \\
\text { to move into lecturing in the topic themselves. }\end{array}$ \\
\hline
\end{tabular}

Table 1 - Boehm's five generations of Music Technologists (Boehm 2007)

In the table above, Boehm neatly contains the five generations of music technologist, starting with the innovators and experimenters. Technology was expensive to create, as the products being devised had not been commercialised and thus music technology was arguably in its infancy. 


\section{First Generation}

The topic of sound engineering, or audio engineering, as our field was once referred to in professional circles (Kealy, 1979), remained in force for considerable time as the craft was developing in the 1950s to 1970's (Zagorski-Thomas, 2014). This neatly aligns to Boehm's first generation. Technologically speaking, this represents a slow start to the industry..

Significant, important and lasting developments took place creating a foundation for seminal recordings, achieved by using innovative and now-treasured analogue equipment. Boehm cited the likes of Moog and Buchla, the innovators of the subtractive synthesiser, and then the composers using these and other technologies such as Stockhausen, Eimert and Cage. Importantly, Pierre Schaeffer is included in this first generation, and in many ways addressed a number of important innovative questions in advance of the technology being readily available to him in the form of the Potentiometre d'espace (primitive surround sound diffusion) and The Morphophone (an early tape based delay unit) amongst other innovations. Obviously, many other innovators dawned from this period, including Les Paul, for example. (Manning, 2004).

\section{Second Generation}

The advent of microprocessor technologies intersecting with electronic keyboard instruments and digital audio equipment, alongside an historic agreement between many competing companies to standardise one very important landmark protocol - the Musical Instrument Digital Interface (MIDI) - introduced a whole new prism by which modern recordings could be conceived and constructed (Théberge, 1997). No longer was the process of making records based solely upon performance of live instruments, and thus musicians. Methods of programming synthesisers, samplers and drum machines made way to, in the 1980's, especially 1983 to 1988 , 'both the marketplace and the very nature of electronic music production [being] completely reorganized' (Théberge, 1997, Slater, 2016). This tallies with Boehm's second generation of music technologists.

Commercialisation is a key feature within Boehm's second generation of music technologists. The 1970's gave rise to mass production of analogue synthesisers, sequencers and later, the origins of the widespread adoption of digital signal processors in digital effects units which shaped much of the technological sound of the 1980's (the AMS RMX16 is a good example of this). The 1980's saw the advent of MIDI and digital audio as a consumer product in the form of the Compact Disc. Both technological developments in personal music creation and consumer listening began an acceptance in the realm of digital audio and spurred on innovation.

\section{Third Generation}

Boehm cited the third generation as the first music technology lecturers to teach the subject, and hence an early recognition of a field. The widespread adoption of lower-cost digital audio recorders and iterative development in the digital audio workstation enabled more institutions to set up music technology offerings. In the mid 1990's the first Music Technology A-Level appeared, from the EDEXCEL board of examiners, now Pearson, which still continues today. It is at this juncture that the field not only contained a trajectory within the higher education sector, with masters and other postgraduate level qualifications (UK Level 7) appearing (the fourth and fifth generations), but also at the lower pre-entry level (UK level 3) sector also. 
Educationally, the term Sound Engineering (or Audio Engineering) appeared to make way for the term 'music technology' to encompass the new digitally biased technology available to the learner. Tankel (1990) notes that the 'recordists' contribution' was moving into what he defines as 'sound design' alongside traditional engineering. By 1990 the field had begun shifting into the realms of the term 'production', adopted by thethird generation. However, it would take another decade before the music production degree within UK higher education became a growing prominence.

This change, we consider, can be evidenced to have been felt both in the academy and in the professional world. King (2016) illustrates the permanent change in training and education in the field around the time of the advent of digital audio. The evidence suggests that the Alesis ADAT digital multitrack recorder provided many studios with the opportunity to 'set-up' an affordable professional standard studio for far less money in the early 1990's than it had previously cost using analogue multi-track tape. Theberge (2012) also notes a shift in education, identifying that '... with the arrival of digital recording in the 1990's' traditional apprenticeships 'virtually disappeared'. Something we'll explore here in more detail later. Many, including one of the authors' own educational experience was only possible due to the affordability of the ADAT and the migration of training moving to the university sector away from those traditional in-work alternatives. The institution in question would never have previously been in a position to afford an open-reel analogue multitrack tape machine, costing over twenty times as much.

\section{Fourth and Fifth Generations}

Boehm originally noted that the fourth generation would be those who graduated with degrees using the phrase 'Music Technology'. Subsequently the fifth generation would be those graduates successfully completing post graduate qualifications in the subject. It is believed that these graduates have integrated into the field which leads us to suggest we've reached a sixth generation of music technologists today. Macedo, (2013) notes that:

'The development of music technology as an academic field is a relatively recent stage in the history of the discipline, corresponding to the fifth generation of music technologist... M. Ferreira (2007) discusses the many challenges posed by music technology as an academic field: the background knowledge expected from students; the repertoire of musical examples and technologies to be included in the curriculum; the variety of students' expectations and different conceptions regarding the nature, methodologies and goals of the discipline"

Macedo identifies, alongside Boehm, that music technology was the discipline that 'never was', and the difficulties it pools together. Discussions relate firstly to the breadth of the topics, or interdisciplinary elements, that make up the subject. Secondly they relate then to the depth that each of those internal disciplines requires to make a proficient 'technologist' is considerable. We explore, as discussed later in this paper, how the subject has morphed in some areas to expand and embrace music production elements into the field of music technology and has now become cemented within a research supported, sixth generation. 


\section{The Sixth Generation of Music Technologist - 'The discipline that became?'}

Today, we conceive the sixth generation of music technologists as those researchers, academics and professionals who have cemented Music Technology \& Music Production as an academic field. In addition, those leaving the fourth and fifth generations have made their way into industry making use of their research credentials.

In 2007, around the time of Boehm's initial publication in this area, Simon Zagorski-Thomas initiated and ran the inaugural Art of Record Production Conference (ARP) in London. Many years later, with mostly bi-annual international events, the ARP conferences have led the field and aided the sixth generation to find outlets in which to publish their papers in the accompanying online Journal on the Art of Record Production (JARP) and launching several key books and partnerships.

In 2013, a set of academics and professionals created the Innovation In Music bi-annual conference series, with a focus more on the new journeys and investigations placed on the industry. Current proceedings from these events are now published as a book through academic publishers Routledge, after a number of self-published titles with KES International, a conference organising body.

This generation, nor the examples above, are to exclude other notable and pre-existing organisations that have either traditionally permitted music technologists to publish. An example of this would be the International Association for the Study of Popular Music (IASPM) created in 1981. The second generation of music technologists, which cover other musical academic disciplines, provided reputable outlets for music technology research over many years. It would be remiss to exclude the Audio Engineering Society (AES) at this juncture who, since the 1940's have provided a technical outlet for research from music technologists, if not billed under that exact title, or field. The AES has been a key outlet for the more technical end of the spectrum and for those who innovate, such as Bob Moog's paper on subtractive synthesis in 1964 or George Massenburg's 1972 paper on the parametric equaliser. Both have changed the way we work, as music technologists, forever.

The ARP and Innovation In Music conferences, as a small and select example, demonstrate that the sixth generation of the music technologist begins to cement the academic field. This is punctuated with notable, and respected, academic publishers valuing and opening their portfolios to the field. There has been a significant rise in the number of books, both monographs and edited volumes, published through major academic publishers such as Oxford University Press, Routledge, Cambridge Companions, Ashgate amongst others. In the early days of the field (in the second generation), most books were unique, but perhaps less academically focussed (third and fourth generations) and were typically published by the then independent British publisher, Focal Press, now an imprint of Routledge.

\begin{tabular}{|l|l|l|l|}
\hline Generation & Given Title & Description & $\begin{array}{l}\text { Subject Title } \\
\text { Predominance }\end{array}$ \\
\hline $\mathbf{1}$ & $\begin{array}{l}\text { Experimenters \& } \\
\text { Innovators }\end{array}$ & See table 1 & $\begin{array}{l}\text { Music } \\
\text { Technology }\end{array}$ \\
\hline $\mathbf{2}$ & 'Commercializers' & See table 1 & Music \\
\hline
\end{tabular}




\begin{tabular}{|l|l|l|l|}
\hline & & & Technology \\
\hline $\mathbf{3}$ & 'First Lecturers' & See table 1 & $\begin{array}{l}\text { Music } \\
\text { Technology }\end{array}$ \\
\hline $\mathbf{4}$ & $\begin{array}{l}\text { First Graduate } \\
\text { Body }\end{array}$ & See table 1 & $\begin{array}{l}\text { Music } \\
\text { Technology }\end{array}$ \\
\hline $\mathbf{6}$ & $\begin{array}{l}\text { First Post } \\
\text { Graduate Body }\end{array}$ & See table 1 & $\begin{array}{l}\text { Music } \\
\text { Technology }\end{array}$ \\
\hline & $\begin{array}{l}\text { The Discipline } \\
\text { That Became }\end{array}$ & $\begin{array}{l}\text { The generation that cemented } \\
\text { Music Technology \& Music } \\
\text { Production as an academic field, } \\
\text { with significant research outputs. } \\
\text { Plus, the fourth and fifth generations } \\
\text { making their skills felt within } \\
\text { industry. }\end{array}$ & $\begin{array}{l}\text { Music } \\
\text { Production }\end{array}$ \\
\hline
\end{tabular}

Table 2 - Boehm's Six Generations of Music Technologist in 2018

The sixth generation of music technologist, we propose is the 'discipline that became'. The discipline has now become an academic field in its own right, even if slightly shifting in terms of identity. By this, we refer of course, to the rise in the interest in the phrase 'music production' within the titles, which we'll explore later in this paper.

\section{What's in a name? : 'Music Technology' \& 'Music Production'}

Boehm (2007) identified a number of interdisciplinary fields that converged to construct a scaffold for music technology building upon Moore (1990). Representing this pictorially, three main fields were cited as contributing to the field, that of Art, Technology and Science. Within these three fields, several, large sub fields were highlighted to offer the reader a flavour of the topics included in each of the 'triad of music technology' (Boehm 2007).

One corner, 'Technology', connected itself with sound engineering and recording style topic matters. 'Record Production' was considered to sit under this title - a nod to the fact that the art of music production had not yet been considered a sub field in its own right. The second corner, 'Science', was perhaps wider to include the engineering, informatics and software \& hardware development. Interestingly, musicology enters this corner. The third corner "Art" contained electro-acoustic work as well as electronic music, sound design and a then popular phrase - 'creative music technology'.

Mark Thorley's (2014) assertion that the job title of a 'Music Technologist' simply didn't and still arguably doesn't exist, is quite pertinent. In much the same way that a degree in 'music' doesn't facilitate the job of a 'music-ist' but a 'Musician', a degree in 'Music Technology' might produce 'Music Technicians' rather than 'Music Technologists' because 'Music Technicians' do exist. Irrespective of this, it must be acknowledged that the term 'Music Technology' has become adopted by the academic community. Confusingly however, teachers and musicians refer to anything that uses technology to support the creation of 
music or indeed, musical learning, as 'Music Technology', further cementing the term as an academic, not a professional one.

The obvious uses of 'Music Technology', as alluded to earlier, ring true for most; sound engineering, composing in a range of styles from popular music to sonic arts/electroacoustic music, producing music, audio technician, software programmers, mixing and mastering engineer etc. Nevertheless, there are some who also put the following in the 'music technology' bracket, some of which are anecdotal: blogging (Chong, 2010); using a mobile phone in a classroom; playing a keyboard (Dillon, T. 2005); using google forms for Assessment for Learning (AfL); uploading a file to a cloud based sharing/storage service. Not surprisingly, none of the latter appeared in one of the UCAS searches as a type of 'Music Technology'. This is, of course, a wider than normal interpretation of the music technology title we're exploring here, but demonstrates an objectification of the term 'Music Technology'.

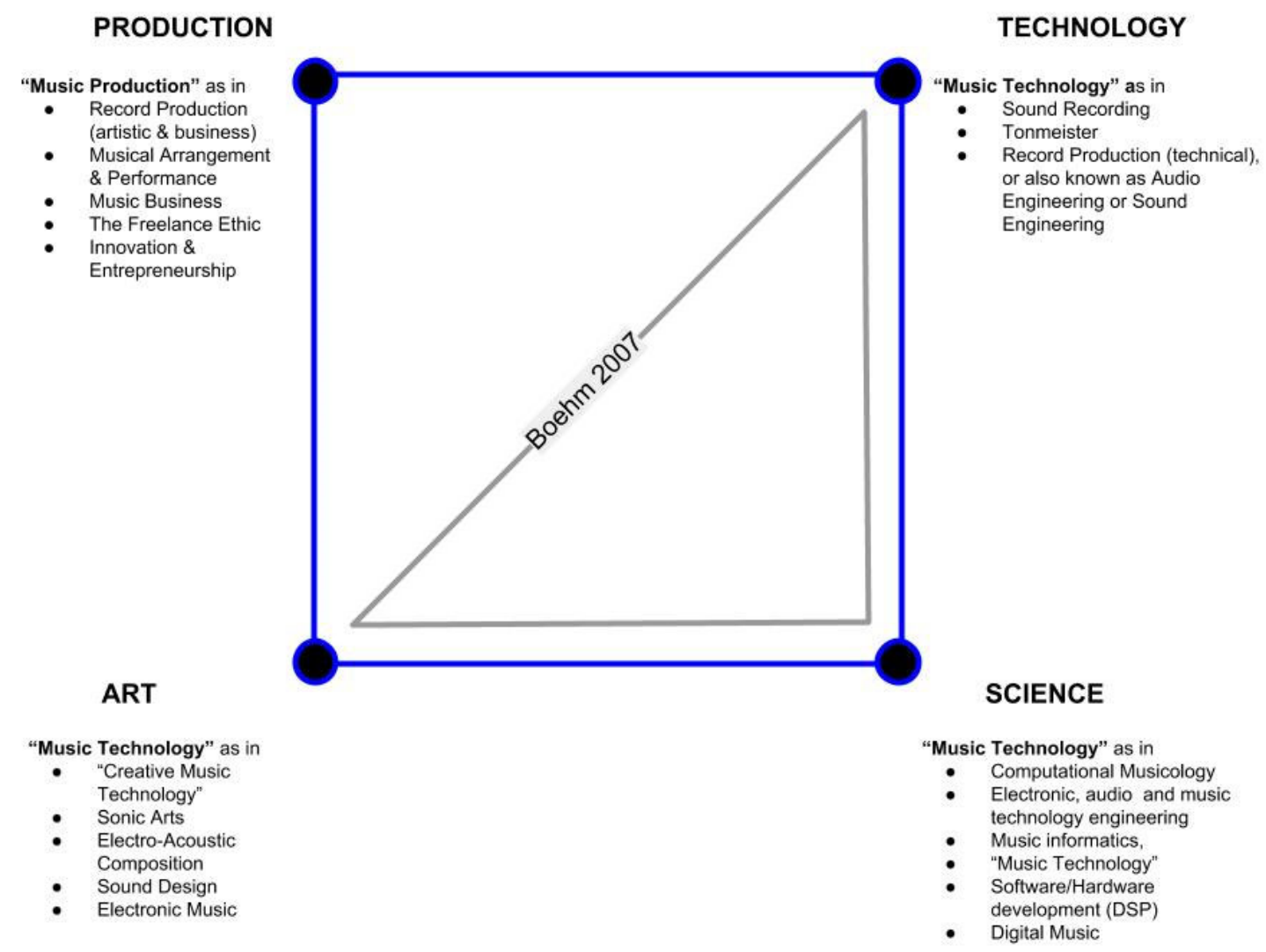

Figure 1 - The Tetrad of Music Technology \& Music Production

Today, in 2018, as we shall explore, we find that the academic field has developed. Degree titles, in 2007, that almost exclusively offered music technology, or courses that alluded to the title of technology in music, have now expanded to the more creative, interdisciplinary, output-focussed title of 'music production'. Crudely it could be perceived that the term 'production' embraces the creative and the 'art' of producing music in a wider context in conjunction with the industry. That context includes the equipment and engineering skills 
anecdotally associated with 'music technology' courses, but also incorporates a number of additional skills considered in 'music production' such as business, entrepreneurship, creativity and musical sensitivity (Hepworth-Sawyer \& Golding, 2010). We feel this is a sufficient enough shift to warrant a four pronged approach to Boehm's triad of the music technologist, thus adding 'Production' into figure 1 above. The data later demonstrates that there has been a large expansion of the term 'production' in relation to degree titles showing a growing interest in the creative application and sonic output of music technology. Admittedly speaking about an allied field around the application of technology and creativity as two co-aligned factors, Mishra \& Yadav (2013) comment that "...creative output is not determined either by only the individual or the technology, but rather through a "partnership" between the two." We begin to see this shift in the titles offered to incoming students.

\section{The higher educational landscape of music technology \& music production in Britain in 2018.}

Our research data was sourced mainly from the Universities and Colleges Admission Service (UCAS), in line with a segment of Boehm's original analysis. During the latter portion of our research, a shift in policy, and thus listings took place at UCAS, meaning data around the sector of music technology began to produce different results, daily. This also coincided with the start of the application cycle for September 2019 entry. Nevertheless this shift in reporting, first observed in April 2018, began to remove listings for some private institutions and thus skewed the wider view of courses on offer. Given this revelation, we persisted with the figures that offered the widest image of the field, and as such our data was accessed on dates before, and including, 4th April 2018.

Boehm's findings in 2007 reported that there were 351 degree courses available within the category of music technology. Those results show that the major proportion of those courses use the actual phrase 'Music Technology' in the title. It is worth pointing out at this juncture that Boehm included course titles which were connected to another subject matter. Not a joint honours exactly, but her findings would have counted the course title 'Audio \& Music Technology' for example in this figure. In our 2018 findings, for the sake of accurate comparison, we continue this approach. Also, later, we explore how many dedicated degrees with the sole title of Music Technology appear in both decades.

Fast forward just over a decade, and we note that the proportion of 'Music Technology' courses have, in fact, increased only slightly from $41.9 \%$ to $42.4 \%$. Meanwhile, as we'll discuss in more detail later, courses with the phrase 'Music Production' in the title has seen a large rise in representation from UK Universities, from just $1.6 \%$ up to $14.6 \%$ of the available course titles within the field. Music Production still features more heavily in the Anglo-American world, specifically UK, as it has dominated the music industry in the EU. Experience indicates that sound engineering as a culturally-neutral discipline (e.g. one that is not tied as much to popular music as UK production courses tend to be) and is still more apparent outside of the UK.

For entry into the 2018-19 academic year there were 32,284 undergraduate courses available at the time of our research from 488 institutions within the UCAS system. A 
significant 387 courses emerge within the search term of 'music technology' taught by 109 different institutions.

These qualifications include listings for courses at both level 4 and level 5 (Certificate of Higher Education and Diploma of Higher Education in addition to Higher National Diplomas) and even some Masters qualifications. For the purposes of our research, and to be able to accurately compare with Boehm's 2007 research, we have included full bachelor degree titles only and report UCAS as offering 27,911 classed as 'Bachelor degrees'. Of these, 314 are in the search term of 'music technology' coming from 84 institutions.

In 2007, Boehm reported that there were 63 different names used with the direct phrase 'music technology'. In 2018-19, the different names including the phrase 'music technology has shifted by one to 62 . In 2018 the total number of courses, with the words 'music' and 'technology' in a title, such as 'Music Composition and Technology for Film \& Games', comes to 171.

In table 3 below, Boehm's original analysis can be found alongside a 2018 representation of the same data. Some subject titles have seemingly gone out of fashion, such as Sonic Music, whereas others have emerged as we'll discuss later, and is accounted for within the 'Rest' category here.

\begin{tabular}{|l|l|l|l|l|}
\hline Degree Name Occurrence & $\begin{array}{l}\mathbf{2 0 0 7} \\
\text { no. }\end{array}$ & $\mathbf{2 0 0 7} \%$ & $\begin{array}{l}\mathbf{2 0 1 8} \\
\text { no. }\end{array}$ & $\mathbf{2 0 1 8} \%$ \\
\hline Music Technology & 131 & $41.9 \%$ & 133 & $42.4 \%$ \\
\hline Media Technology & 36 & $11.5 \%$ & 1 & $0.3 \%$ \\
\hline Electronic Music & 31 & $9.9 \%$ & 6 & $1.9 \%$ \\
\hline Sonic Music & 22 & $7.0 \%$ & 0 & $0.0 \%$ \\
\hline Creative Music Technology & 20 & $6.4 \%$ & 17 & $5.4 \%$ \\
\hline Audio Technology & 10 & $3.2 \%$ & 1 & $0.3 \%$ \\
\hline Music Production & 5 & $1.6 \%$ & 46 & $14.6 \%$ \\
\hline Recording & 4 & $1.3 \%$ & 7 & $2.2 \%$ \\
\hline Sound Engineering & 3 & $1.0 \%$ & 4 & $1.3 \%$ \\
\hline Rest & 51 & $16.3 \%$ & 99 & $31.5 \%$ \\
\hline
\end{tabular}

Table 3 - Degree name occurrences

In our research, it was odd to note that some of the categorisation, whether institutional choice, or internal UCAS selection, excluded BSc in Music, Production and Sound Science from Salford University within the search of Music Technology. 
The key element to draw from the results shown in table 3, is the significant increase in Music Production titled programmes. In 2007 there were just 5 courses, but this figure rises to 46 in 2018 despite only representing $14.6 \%$. Boehm (2007) notes that it's 'arguable whether or not some of these [course] terms belong in the [music technology] category (e.g. audio engineering, or media technology)". It is interesting to comment that these perceptions and delineations of the field are also somewhat blurred too in 2018 for some titles, but perhaps not 'music production'.

It was also noted in the 2007 study that a number of institutions with the phrase 'music technology' within the title were in fact joint honours programmes. These include courses entitled 'Music Technology and Egyptology', 'Music Technology and International Politics and Policy' or with an extra 'and' in such as 'Music and Technology with Egyptology'. Figure 2 below demonstrates that 54 institutions offer just one degree in the field and 17 institutions offer 2 titles. There is then a steady increase in the amount of degrees offered with two institutions offering ten course titles in the field. Above this, a slight rise continues to 11 degrees, then 17 degrees, both offered by one institution each, then 18, then 20 degrees and a final dramatic increase to one institution offering a staggering 80 titles. On average, the number of degrees offered per institution was 3.62 titles. Interestingly removing the one institution with the 80 titles, the average reduces to 2.9 courses.

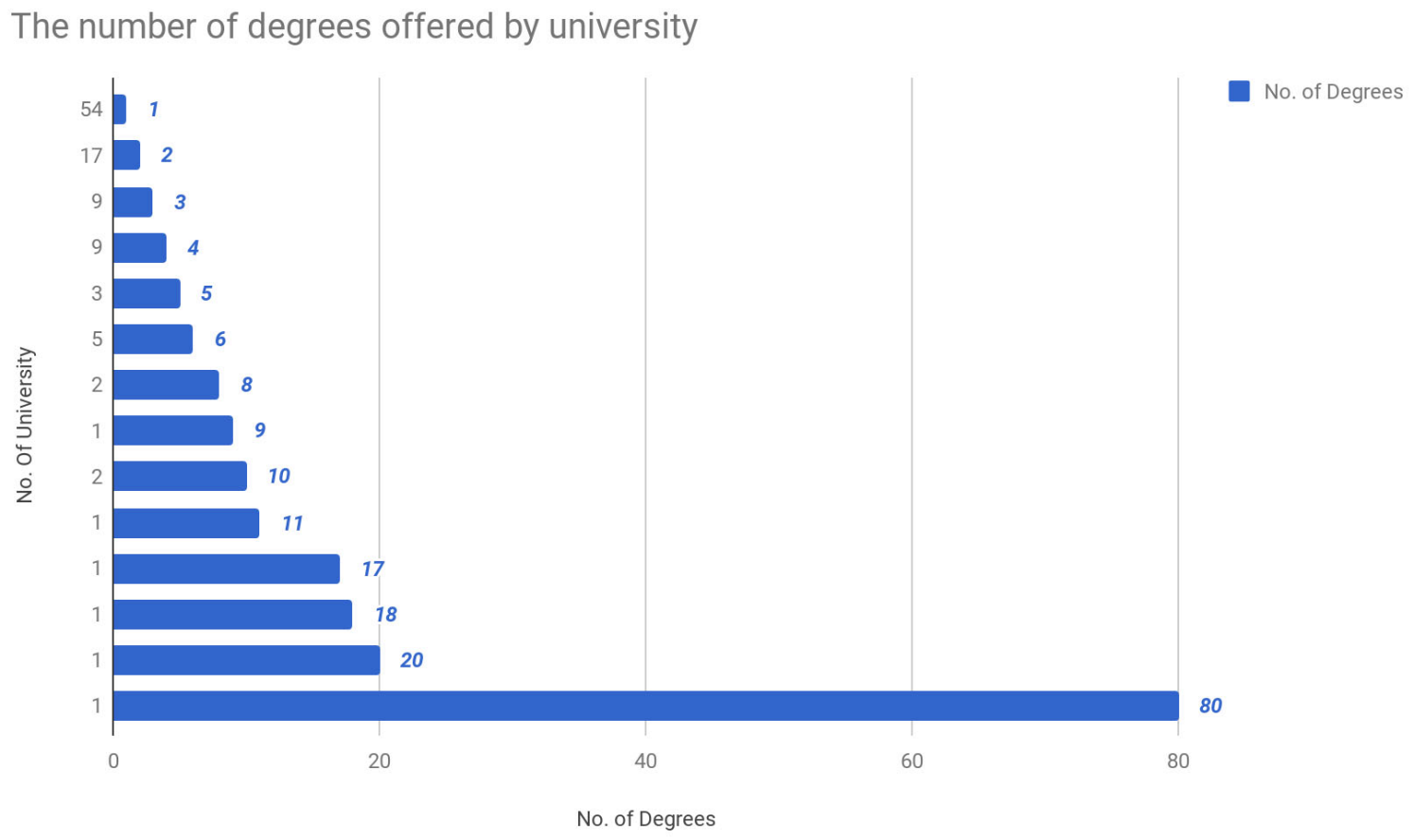

Figure 2 - The number of degree courses offered by the number of universities In 2018 , the average number of degrees per institution is 3.62 .

In 2007 Boehm reported that the majority of qualifications were provided as Bachelor of Science (BSc), at 55\% (195 courses) followed by the Bachelor of Arts (BA) at 39\% (137 courses). Over the past decade there appears to have been quite a shift, with BSc programmes only taking $16.9 \%$ (53 courses) of the field whereas the BA programmes dominate with a large $77.4 \%$ (243 listings) as shown in figure 3 below. Boehm, in her 2007 report, mentions the then educational policy was to encourage science courses (via a 
governmental financial incentive), however since that time, a shift away from BSc has occurred. Interestingly, at the time of writing, there are several government discussions and policies about the importance of Science, Technology, Engineering and Maths (STEM) in education, typically at school level. From our personal experience, there have not yet been many actionable dictats at university level to shift in this direction, but given significant changes in university regulation and governmental attention, due to the white paper on higher education in 2016 entitled "Success as a Knowledge Economy: Teaching Excellence, Social Mobility and Student Choice" and the Higher Education and Research Bill that followed, it's quite possible shifts may soon occur. The paper and bill enabled an enormous shake up including the subsequent wind up of the Higher Education Funding Council for England (HEFCE) and the launch of the Office for Students (OfS) as well as the launch of the controversial Teaching Excellence Framework (TEF).

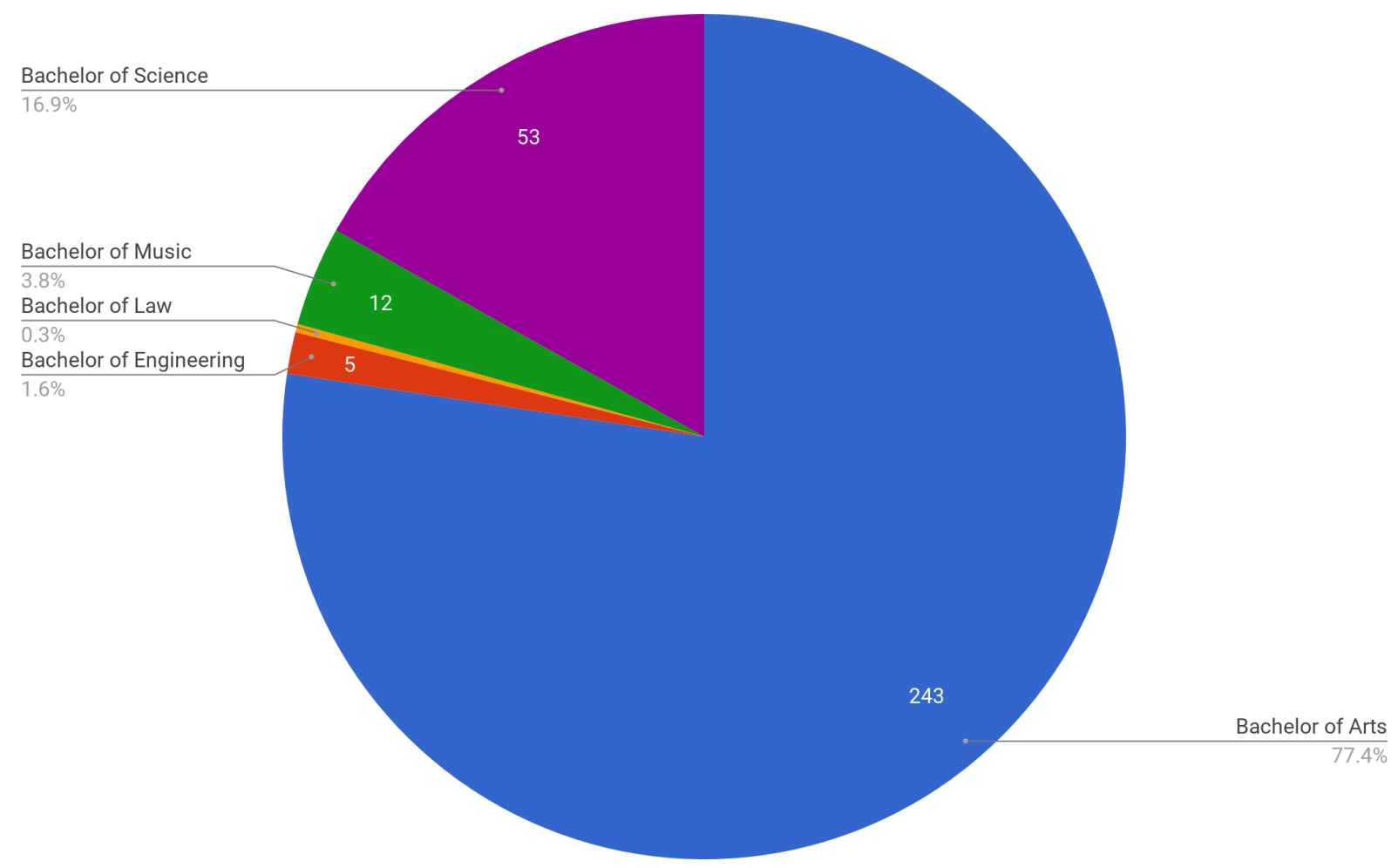

Figure 3 - types of degree qualification available under the search term 'music technology'. The Bachelor of Law has only one programme.

It was also noted in the 2007 study that 35 degree titles offered sandwich course options (those courses offering a year's placement, typically, within a company or an option to study for a year abroad) compared to just 32 in 2018-19.

In 2018, there are still a considerable number of joint titled offerings with music technology in the title, as mentioned earlier. Some are sensible 'joinings' such as Broadcast Audio and Music Technology, or, Music Technology and Production, both showing an enhancement to just music technology, and are arguably not strictly 'joint' courses. There are, of course, several courses that join disparate subject matters, which appear quite unnatural coincidences, such as Ancient History with Music Technology. Most programmes are still 
offered across more than one department, with the model of 'interdisciplinarity' even more established one decade on (Boehm 2007).

\section{What of interdisciplinarity versus industry relevance?}

Interdisciplinarity featured as a key closing point in Boehm's 2007 paper, and it is noted that this was highly cited in the decade since. The massification (Trowler, P; Saunders, M \& Bamber, V. 2012) of the Higher Education sector, coupled with the aforementioned drop in apprenticeships since the early 1990s - as previously reported by Theberge (2012) - resulted in an obvious boom in interdisciplinarity across the country. This wave of interdisciplinarity and, more so, joint honours bachelor's degrees, has produced a smorgasbord of course choice. These courses tend to exist on the fringes of the traditional disciplines, which themselves rely on a heavy knowledge base of learning and assessment (Bleazby, 2015).

Writing in 2005, Boehm refers to "Glue Courses" that emerged and that reside between the more traditional disciplines of music and engineering. It now appears that these "glue courses", or modules, are the main, or only, modules available in the majority of undergraduate courses being offered. The real 'glue' courses now tend to be collaborative, devised projects between Performing Arts and Media subjects within institutions. This builds upon Ferreira's idea that Music Technology can be used as a basis to gel and construct work by students from different arts disciplines (Ferreira 2007: 24), Otondo's work (2013) finds that students from different backgrounds such as "film, dance, theatre and fine arts worked together in groups developing projects with an emphasis on the role of spatialized sound in creative practice" (Otondo 2013: 185). From this project it is interesting to note that technical and subject knowledge was not deemed to be important in the collaborative process, and that the students could work together to produce effective sound spalization pieces using their "generic skills rather than specific technical skills linked to their specific disciplines" (Otondo 2013: 185).

There is increasingly a new offering in the landscape between apprenticeship and degree in the 'Music Technology' landscape. The idea of situated learning and of having a cognitive apprenticeship have been mooted by Waltzer (2017) whilst critically looking into the connections between higher education and employment sectors in regards to 'Music Technology'. The concept of having a master/lecturer/teacher breaking down processes for apprentices to follow, is something that was looked at by Davis, R. et al in their 2013 paper 'Preparing the music technology toolbox: Addressing the education-industry dilemma'. Academics at Leeds Beckett University created a 2 week enrichment project best described as a "simulated industry experience where visiting artists work with students on a defined project over the period of two weeks" (Davis, R. et al. 2013). The more traditional recording studio apprentice route tended to take anywhere between two to six years to move from 'studio runner' to 'running a session'. However, during the simulated industry experience project, students would experience this in a highly condensed form, thus gaining the experience of running a session far quicker it is argued. This model is still being used at Leeds Beckett University as reported at the Music Production Education Conference in 2017 in a presentation by Jez Willis.

Sandwich courses have been offering a similar facility in music technology degrees for some time, and they are generally favoured by the student for the generic, soft-skills they offer as 
well as the chance to see the organizational structure of a business first hand. Moreover students are provided with affirmation of their chosen career path or provided options to deviate from their previously designated career choice. Employers also comment that the soft-skills students develop during their placement year stands them apart from their fellow graduates (Priest, 2010). Priest highlights in his 2010 paper, 'The value of placements to undergraduate BSc (Hons) Music Technology students', that both student and employer are clearly in favour of the scheme and what benefits it provides to a graduate. As Priest is the first to point out, the statistical data from students' academic performance overall is inconclusive. What was clear from Priest's data, was that $36.84 \%$ of students who undertook a placement achieved a First class honours degree, compared with just $5.41 \%$ who did not elect to take a year's placement. Reflecting on this data, Priest says this: "the most motivated students have the drive to pursue and undertake a placement.... it is no surprise that this determination carries over into their studies in the final year." (Priest, R. 2010).

Despite this obvious evidence, there is a distinct imbalance between the amount of graduates that are being produced compared to the amount of roles that are available in the music technology/production sector for those graduates (Priest, M. 2010). Add to that the rise of communications technologies over recent years, and we see the amount of these roles falling further still (Thorley, M. 2014).

Otondos' 2016 paper on 'Music technology, composition teaching and employability skills' highlights a disparity between students views on what skills are needed compared to what employers believe are essential qualities from our graduates. Surveying 18 Lancaster University students and 23 industry employers, Otondo found that undergraduates felt that 'technology based skills' were the most important generic skill to have upon graduating, yet the employers had 'technology skills' considerably further down the list. The employers had 'communication' as by far the most desirable generic skill that they wanted from graduates, whereas the undergraduates didn't see that as important as having 'technical skills'.

Employers also noted that in order to make composition teaching more relevant to professional practice, that they should be given coursework tasks that are connected to specific industries within the Music Technology sector and have stricter project briefs. Employers seem to continue to ask for more generic skills from their graduates. A mixture of job-specific skills with other 'soft' skills such as "communication, working with others, IT, research, self-development and problem solving" (Brown, 2007) are required by employers.

Furthermore, employers comment that a lack of generic soft skills from our graduates prevent organizations from employing them (Bachelor, L. 2012), and herein lies the inflated and more pressing problem. For the last ten years, there has been a government shift in educational policy in British schools towards E.D. Hirsch's idea of a knowledge-based curriculum (Hirsch, Jr., E. D. 1987), where there are no cross curricular projects or skills, and emphasis is placed on purely discrete and traditional 'disciplines', has been championed by Nick Gibb MP and Michael Gove MP for example. Multi-Academy Trusts (MAT's), Schools and Teachers across the country have been employing a 'knowledge' based curriculum with an emphasis on learning by 'rote'. Teachers are being taught that generic skills cannot be transferred between disciplines and that "project based work overloads working memory" (Christodoulou, D. 2017). 
Universities are inheriting these students who are used to remembering 'facts' and recalling from their long term memory, but have little experience of problem solving and working in pseudo working environments. Universities have a harder job now of bridging this gap between 'schooling' and 'employment' because of this 'push and pull' from both their input; the state schooling sector, and their output; the employers. In the creative sector at least, it seems that they do not require these 'facts' but would rather have 'communication skills' and real 'working world experience' (Bakhshi et al. 2013: 103) (Crebert, G. et al 2007). In Brooks and Everett's 2009 paper, 'Post-graduation reflections on the value of a degree' students talk about an undergraduate degree offering no "more than a 'basic minimum' within a competitive graduate labour market." (Brooks, R. Everett, G. 2009). And that "postgraduate qualifications and other forms of formal learning were widely seen as providing the bridges into employment".(Brooks, R. Everett, G. 2009). With the current trend of incoming undergraduate students lacking in generic skills, institutions face pressure from students and employers to bridge this ever widening gap, and so face the very real danger of becoming places to merely prepare young people for employment rather than focussing on a more holistic conceptualisation of academic learning and research.

\section{Conclusion}

Boehm's last paragraph in 2007 called for daring, flourishing research and teaching at the boundaries of those coinciding disciplines - '...spaces where new theories emerge out of inquiry... informed, but not bound by pre-existing schools of thought'. Sadly, in 2018 we report that there is a looming, yet, significant threat to Boehm's call. The ability to cross collaborate across disciplines, whilst currently still on offer in British higher education, is something that is rejected in the school curriculum, and will have an incalculable impact on music technology education in HE for decades to come.

\section{Bibliography}

Bakhshi, H., Hargreaves, I. and Mateos-Garcia, J. (2013), A Manifesto for the Creative Economy, London: Nesta, p. 103.

Bleazby, J. (2015) Why some school subjects have a higher status than others: The epistemology of the traditional curriculum hierarchy, Oxford Review of Education, 41:5, 671689

Boehm, C. (2005), 'Music Technology in Higher Education', The Idea of Education, ed. by Tom Claes. Inter-Disciplinary Press, Vol. 12. 2005.

Boehm, C. (2007). 'The discipline that never was: current developments in music technology in higher education in Britain'. Journal of Music, Technology \& Education 1:3 pp. 7-21. 
Brooks, R. Everett, G. (2009), 'Post-graduation reflections on the value of a degree', British Educational Research Journal, Vol. 35, No. 3, pp. 333-349

Brown, R. (2007). 'Enhancing student employability? Current practice and student experience in HE performing arts', Arts and Humanities in Higher Education, 6: 1, pp. 28-49

Chong, E. K. M. (2010), 'Blogging transforming music learning and teaching: Reflections of a teacher-researcher', Journal of Music, Technology and Education, 3: 2+3, pp. 167-181

Christodoulou, D. (2017), 'Making Good Progress. The future of Assessment for Learning. Oxford: Oxford University Press.

Crebert, G. Bates, M. Bell, B. Patrick, C \& Cragnolini, V. (2007) Developing generic skills at university, during work placement and in employment: graduates' perceptions, Higher Education Research \& Development, 23:2, 147-165

Davis, R., Parker, S. and Thompson, P. (2014), 'Preparing the music technology toolbox:

Addressing the education-industry dilemma', Journal of Music, Technology \& Education $7: 3$, pp. 313-323

Denicolo, P., \& Pope, M. (1990). Adults learning - Teachers thinking. In C. Day, M.Pope, \& P. Denicolo (Eds), Insight into teachers thinking and practice (pp.147-160. London: Falmer

Department for Education and Skills (DfES) (2003). The future of higher education, Norwich: The Stationery Office. Cm. 5735.

Department for Business, Innovation and Skills (2016). Higher education: success as a knowledge economy - white paper (https://www.gov.uk/government/publications/highereducation-success-as-a-knowledge-economy-white-paper) accessed 04/04/2018

Dillon, T. (2005). 'Current and Future Practices:Embedding Collaborative Music Technologies in Secondary Schools', Music Education with Digital Technologies, pp118127.

Ferreira, G. M. D. S. (2007), 'Crossing borders: Issues in music technology education', Journal of Music, Technology and Education, 1: 1, pp. 23-35.

Hirsch, Jr., E. D., (1987). Cultural Literacy: What Every American Needs to Know. Boston: Houghton Mifflin.

Kealy, E. (1979). From Craft to Art: The Case of Sound Mixers and Popular Music. Work and Occupations, 6(1), pp.3-29.

King, A. (2016). Studio Pedagogy: Perspectives from Record Producers. In King, A. \& Himonides, E. (eds.) Music, Technology \& Education: Critical Perspectives. Ashgate

Macedo, F. (2013), 'Teaching creative music technology in higher education: A phenomenological approach'. Journal of Music, Technology \& Education, 6:2, pp 207-219. 
Manning, P. (2004), Electronic \& Computer Music, Oxford University Press

Massenburg, G., (1972), Parametric equalization. In Audio Engineering Society Convention 42. Audio Engineering Society.

Bachelor, L. (2012) 'Work: The hard truth about soft skills: Graduate careers: Qualifications are fine, but most employers are now looking for a more human touch.' The Guardian, 9 June 2012, p. 4. General OneFile, http://link.galegroup.com/apps/doc/A292461392/ITOF?u=uce\&sid=ITOF\&xid=64096144. Accessed 23 Apr. 2018.

Mishra, P. \& Yadav, A. (2013), Rethinking Technology \& Creativity in the 21st Century TechTrends 57: 10.

Otondo, F. (2016), 'Music technology, composition teaching and employability skills', Journal of Music, Technology \& Education, 9: 3, pp. 229-240

Pope, M., \& Denicolo, P. (1993). The art and science of constructivist research in teacher thinking. Teacher and Teacher Education, 9. 529-544.

Pope, M., \& Denicolo, P. (Eds). (1997). Sharing understanding and practice. Farnborough, UK: European Personal Construct Association Publications.

Priest, R. (2010), 'The value of placements to undergraduate BSc (Hons) Music Technology students', Journal of Music, Technology and Education, 3: 1, pp. 47-65

Slater, M. (2016), 'Processes of learning in the Project Studio'. Music, Technology \& Education: Critical Perspectives, Ashgate

Tankel, J. D. (1990), The Practice of Recording Music: Remixing as Recording. Journal of Communication, 40: 34-46.

Théberge, P., (1997). Any Sound You Can Imagine: Making Music/Consuming Technology. Wesleyan University Press

Théberge, P., (2012). The End of The World As We Know It: The changing role of the studio in the age of the Internet. In Frith, S. \& Zagorski Thomas, S. (eds), The Art of Record Production. Ashgate.

Thorley, M. (2005), Music Technology education - who is the customer, the student or the industry? Leeds: LIMTEC 2005.

Thorley, M., (2014). 'Graduate meets employer-a model for embedding industry professional involvement in the development and assessment of student portfolios'. Journal of Music, Technology \& Education, 7(3), pp.325-329. 
Trowler, P; Saunders, M \& Bamber, V. (2012) 'Tribes and territories in the 21st century: Rethinking the significance of disciplines in Higher Education'

UCAS Directory $(2017,2018)$, https://digital.ucas.com/search

Waltzer, D.A. (2017), 'The Curricular Soundtrack: Designing Interdisciplinary Music Technology Degrees Through Cognitive Apprenticeship and Situated Learning.', New Directions for Computing Education: p.143-160

Zagorski-Thomas, S. (2014). The Musicology of Record Production., Cambridge University Press, Cambridge.

\section{Suggested Citation}

Boehm, C., Hepworth-Sawyer, R., Hughes, N., Ziemba, D. (2018), "The discipline that 'became': developments in music technology and music production in British higher education between 2007 and 2018'. Journal of Music, Technology and Education...

\section{Contributor details}

Russ Hepworth-Sawyer is a professional mastering engineer and currently a part time senior lecturer of Music Production at York St John University. Russ, alongside his professional career has formerly taught at London College of Music, Leeds College of Music and Rose Bruford College. Russ has written several titles for Focal Press and Routledge and edits their Perspectives on Music Production series. Since 2013, Russ alongside other academics has run the Innovation in Music conference series and proceedings books in addition to the more recent Music Production Education Conference (MPEC). Russ is currently undertaking doctoral study at Leeds University on audio mastering education.

Nick Hughes is a music technology and music teacher at a secondary state school in south Leicestershire; Robert Smyth Academy. He is currently Head of Faculty within the school and is responsible for music, drama and dance subjects at all key stages. Nick has recently been appointed Principal Examiner for AS Music Technology by Pearson Edexcel and has previously examined Music Technology at A2 level for 6 years. He is a research student at Birmingham City University and is working towards a Masters in Teaching and Learning with a focus on teaching composing using technology. 
Dawid Ziemba is an undergraduate student at York St John University studying Music Production. Dawid is a member of the Students As Researchers team at the university and has made a significant contribution to this project,

Carola Boehm holds degrees in music, computer science and electrical engineering and is one of the founding editorial board members of the Journal of Music, Technology and Education (Intellect). She is currently Professor of Arts and Higher Education at Staffordshire University and has held positions at the University of Glasgow, Manchester Metropolitan University, the University of Mainz (Germany), the Conservatory of Music in Hanover (Germany) and Den Haag (Netherlands), as well as being self-employed in the 90s. Her research areas include music technology education, community music, and the interplay of interdisciplinarity, creativity and technology in higher education. Her most recent work considers the role of universities for the arts sector, considering how new ways of creative co-creation and knowledge production provide new structures for gaining sustainable collaborative partnerships between arts, academia and the public. 